\title{
Effect of atmospheric organic complexation on iron-bearing dust solubility
}

\author{
R. Paris and K. V. Desboeufs \\ LISA, UMR CNRS 7583, Université Paris Est Créteil (UPEC) et Université Paris Diderot (UPD), Institut Pierre Simon \\ Laplace, Paris, France
}

Correspondence to: K. V. Desboeufs (desboeufs@lisa.u-pec.fr)

Received: 12 December 2012 - Published in Atmos. Chem. Phys. Discuss.: 4 February 2013

Revised: 16 April 2013 - Accepted: 18 April 2013 - Published: 14 May 2013

\begin{abstract}
Recent studies reported that the effect of organic complexation may be a potentially important process to be considered by models estimating atmospheric iron flux to the ocean. In this study, we investigated this process effect by a series of dissolution experiments on iron-bearing dust in the presence or the absence of various organic compounds (acetate, formate, oxalate, malonate, succinate, glutarate, glycolate, lactate, tartrate and humic acid as an analogue of humic like substances, HULIS) typically found in atmospheric waters. Only 4 of tested organic ligands (oxalate, malonate, tartrate and humic acid) caused an enhancement of iron solubility which was associated with an increase of dissolved $\mathrm{Fe}$ (II) concentrations. For all of these organic ligands, a positive linear dependence of iron solubility to organic concentrations was observed and showed that the extent of organic complexation on iron solubility decreased in the following order: oxalate $>$ malonate $=$ tartrate $>$ humic acid. This was attributed to the ability of electron donors of organic ligands and implies a reductive ligand-promoted dissolution. This study confirms that among the known atmospheric organic binding ligands of $\mathrm{Fe}$, oxalate is the most effective ligand promoting dust iron solubility and showed, for the first time, the potential effect of HULIS on iron dissolution under atmospheric conditions.
\end{abstract}

\section{Introduction}

Iron bioavailability has been shown to limit or co-limit primary productivity in a large portion of the world ocean (Martin et al., 1994). A significant external iron source to the open ocean is atmospheric input and particularly the atmospheric deposition of mineral dust from continental regions (Jickells et al., 2005). The wet deposition seems to be the major dust removal process over ocean regions (Sarthou et al., 2003) and is the most efficient for input of nutrients to the oceans since a significant part of the dust can be previously dissolved in droplets. Presently, the mechanisms controlling the release of $\mathrm{Fe}$ from atmospheric particles into the aqueous phase are not well understood. Measurements of iron solubility during the atmospheric dust cycle suggest a much higher solubility in transported aerosols, implying substantial atmospheric chemical processing. Atmospheric chemical processes affect $\mathrm{Fe}$ speciation and solubility (Desboeufs et al., 2001; Hand et al., 2004), and hence its bioavailability in the ocean. Among these processes, organic complexation enables both enhancing the iron solubility, in particular with oxalate (Sulzberger and Laubscher 1995; Paris et al., 2011), and to stabilising iron in dissolved form after wet deposition in seawater (Kieber et al. 2005). Thus, the atmospheric organic complexation of iron in cloud- or rainwater could be essential to estimate the supply of bioavailable iron to the ocean (Shi et al., 2012).

In marine systems, increased $\mathrm{Fe}$ solubility is known to result from complexation with prokaryotic-released organic matter (OM) such as siderophores as well as low molecular weight polycarboxylate compounds (Barbeau, 2006), humic substances (Laglera and van den Berg, 2009) and saccharides (Hassler et al., 2011). While siderophores are not produced in atmospheric aqueous phase, (poly)carboxylic acids, humic substances and sugars have been detected in rainwater and in the water soluble fraction of aerosol particles (e.g. Wiley et al., 2008). However, the presence of sugar seems to be limited to biomass burning aerosols (Mayol-Bracero et al., 2002) 
or primary biological aerosol particles (Graham et al., 2003). Carboxylic acids contribute significantly to atmospheric water acidity in urban areas (Peña et al. 2002), and can be the main contributor to acidity (70\%) in remote (dusty) areas (Gioda et al., 2009; Desboeufs et al. 2010). Formic and acetic acids constitute the most abundant carboxylic acids in cloudand rainwater (Peña et al., 2002). In all the regions, oxalic (C2), malonic (C3) succinic (C4) and glutaric (C5) acids are usually the most abundant dicarboxylic acids, more concentrated than ketoacids, such as glyoxalic acid, or hydroxyacids, such as glycolic and lactic acids (Sempéré and Kawamura 1996; Desboeufs et al., 2010). The contribution of organic acids to total dissolved organic carbon (DOC) ranges from only $14-36 \%$ (Altieri et al., 2009). A large part of the rainwater DOC has been attributed to macromolecular organic matter, termed humic like substances (HULIS) because of properties similar to terrestrial and aquatic humic and fulvic acids (Graber and Rudich, 2006). These HULIS are usually identified in rain- and cloud waters, but not quantified (e.g. Muller et al., 2008). Several field studies have reported observations of dust mixed with organic species, mostly of short-chain oxygenated hydrocarbons and carboxylic acids (Russell et al., 2002; Falkovich et al., 2004; Sullivan et al., 2007). Observations of rain samples which contained both dust and organic species have been also reported (Buck et al., 2010; Desboeufs et al., 2010).

Among the organic compounds found in rainwater, Okochi and Brimblecombe (2002) studied, by theoretical calculations, the potential ligands of iron under atmospheric conditions. They reported that the simple monocarboxylic acids (e.g. formic and acetic) do not complex substantial amounts of metal under typical atmospheric conditions. On the contrary, the dicarboxylic oxalic and malonic acids, which are strong acids and have high Henry's law constants and large stability constants, lead to substantial iron complexation at very low concentrations (around ppt). The hydroxylated carboxylic acids, such as glycolic and tartaric acids, are less volatile, and relatively strong acids could be more effective than monocarboxylic acids to complex iron under atmospheric conditions. Humic substances are known to provide binding sites, due to the presence of phenolate or carboxylate groups, for iron in aquatic systems (Allard et al., 2004; Weber et al., 2006). Similar complexation could be observed for HULIS in the atmospheric waters. Thus, it appears that some of the most important organic compounds present in the aerosols and atmospheric aqueous phases are potentially preferred ligands of iron. The organic speciation of Fe(II) and $\mathrm{Fe}(\mathrm{IIII})$ in rainwaters has been only highlighted under natural conditions by thermodynamical calculation (Okochi and Brimblecombe, 2002) or by indirect ferrozine method (Kieber et al., 2005). However, recent works of Cheize et al. (2012) showed by cathodic stripping voltammetry that $80 \%$ or more of dissolved $\mathrm{Fe}(\mathrm{III})$ present in rain samples was bound with a natural strong organic binding ligand, whose stability constant is close to those of siderophores. These re- sults point out the potential role of organic complexation on the dissolved iron concentrations in rainwaters.

Several laboratory studies have shown that some organic ligands promote iron dissolution from iron-bearing minerals and ambient aerosols (Pehkonen et al., 1993; Siefert et al., 1994; Majestic et al., 2006; Xu and Gao, 2008; Upadhyay et al., 2011; Paris et al., 2011). However, these works were limited to the main organic carboxylic acids(i.e. Space formate, acetate and oxalate) found in atmospheric waters. Moreover, the used concentrations of organic compounds were often 50 to 600 times higher than atmospheric concentrations in rainwater. This makes extrapolation of the conclusions of these works to atmospheric conditions difficult. The conclusions obtained from field measurements are also unclear since some studies have suggested a positive effect of organic complexation on dust iron solubility (Zhu et al., 1993; Johansen et al., 2000; Chen and Siefert; 2004), whereas other works have not shown correlations between aerosol iron solubility and oxalate concentrations in the collected rain samples or in the water soluble fraction of aerosols (e.g. Buck et al., 2006, 2010; Paris et al., 2010). Nevertheless, the destruction of oxalate associated with the production of soluble iron (Siffert and Sulzberger, 1991; Zuo 1995, Cwiertny et al., 2008) could explain this lack of correlation. Moreover, during field studies, several factors regarding the iron solubility measurements could act simultaneously, such as acid species, photochemical reactions, and dust mineralogical composition (Baker and Croot, 2010), making it difficult to determinate the involved processes in the dissolution of iron. Thus, despite the profound significance of Fe-organic ligands in rainwater, virtually nothing is known regarding the nature of these ligand(s) and their quantification of complexation effect on Fe solubility.

The aim of this paper is to test the effect of previously identified atmospheric iron-binding ligands on the solubility of iron from mineral dust, i.e. monocarboxylate (acetate and formate), dicarboxylate (oxalate, malonate, succinate and glutarate), hydroxylated dicarboxylate (glycolate, lactate and tartrate) and humic acid as an analogue of HULIS. Fe solubility is affected by the origin of aerosol, which determines the mineralogical speciation of aerosol iron (Journet et al., 2008), the resulting extract $\mathrm{pH}$ (Desboeufs et al., 2003a) and the size of particles (Ooki et al., 2009). In consequence, it is important to control the particulate matter in order to be able to compare the effect of organic ligands. Thus, dissolution studies were conducted using a proxy of Sahelian dust representative of the emission region. These experiments were performed with leaching solutions of organic ligands at typical concentrations found in rainwater. 
Table 1. Chemical characteristics of organic compounds and the range of concentrations measured in rainwater collected in various environments.

\begin{tabular}{|c|c|c|c|c|c|c|c|}
\hline \multirow[t]{2}{*}{ Compounds } & \multirow[t]{2}{*}{ Supplier (purity) } & \multirow[t]{2}{*}{ Dentate form at $\mathrm{pH} 4.7$} & \multicolumn{2}{|c|}{ Acid dissociation ${ }^{1}$} & \multicolumn{2}{|c|}{$\log K_{\mathrm{FeL}}{ }^{2}$} & \multirow{2}{*}{$\begin{array}{c}\text { Rainwater } \\
\text { concentration } \\
(\mu \mathrm{M})^{3}\end{array}$} \\
\hline & & & $\mathrm{pK}_{\mathrm{a} 1}$ & $\mathrm{pK}_{\mathrm{a} 2}$ & $\mathrm{Fe}^{2+}$ & $\mathrm{Fe}^{3+}$ & \\
\hline Formate & Aldrich $^{\circledR}($ ACS grade, $>99 \%)$ & $\mathrm{H}-\mathrm{COO}^{-}$ & 3.7 & & & 3.1 & $0.6-13$ \\
\hline Acetate & Aldrich $^{\circledR}($ ACS grade, $>99 \%)$ & $\mathrm{CH}_{3}-\mathrm{COOH} / \mathrm{CH}_{3}-\mathrm{COO}^{-}$ & 4.8 & & & 3.4 & $0.2-15$ \\
\hline Glycolate & Acros organics $(97 \%)$ & $\mathrm{CHO}_{-} \mathrm{COO}^{-}$ & 3.8 & - & 1.9 & 3.5 & No data \\
\hline Oxalate & Prolabo $^{\circledR}$ (Normapur, $99.8 \%$ ) & ${ }^{-} \mathrm{OOC}_{-} \mathrm{COO}^{-}$ & 1.3 & 4.3 & 4.2 & 9.4 & $0.3-5$ \\
\hline Malonate & Prolabo $^{\circledR}$ (Rectapur, $\left.99 \%\right)$ & $-\mathrm{OOC}-\left(\mathrm{CH}_{2}\right)-\mathrm{COOH}$ & 2.8 & 5.7 & 3.3 & 9.4 & $0.02-2$ \\
\hline Succinate & Fischer Chemical (extrapur, > 99\%) & $-\mathrm{OOC}-\left(\mathrm{CH}_{2}\right)_{2}-\mathrm{COOH}$ & 4.2 & 5.6 & 2.4 & 8.8 & $0.04-1.3$ \\
\hline Glutarate & Acros Organics $(99 \%)$ & $-\mathrm{OOC}-\left(\mathrm{CH}_{2}\right)_{3}-\mathrm{COOH}$ & 4.3 & 5.4 & - & 8.7 & $0.01-0.7$ \\
\hline Tartrate & Prolabo $^{\circledR}$ (Normapur, $99.8 \%$ ) & ${ }^{-} \mathrm{O}_{2} \mathrm{CCH}(\mathrm{OH}) \mathrm{CH}(\mathrm{OH}) \mathrm{CO}_{2}^{-}$ & 3.0 & 4.4 & 2.6 & 6.9 & No data \\
\hline Lactate & Acros Organics $(99 \%)$ & $\mathrm{CH}_{3}-\mathrm{CH}_{2}(\mathrm{OH})-\mathrm{COO}^{-}$ & 3.9 & - & - & - & $1.3-6$ \\
\hline Humic Acid & IHSS, Suwannee River HA (Standard II) ${ }^{4}$ & & - & - & $5.0-5.6$ & 21.3 & No data \\
\hline
\end{tabular}

\section{Materials and methods}

\subsection{Material source}

The experiments were carried out with a sieved fraction of Sahelian soil $(<20 \mu \mathrm{m})$ used as analogue of dust. The soil sample was collected in the area of Banizoumbou, Niger $\left(13^{\circ} 31^{\prime} \mathrm{N}, 2^{\circ} 38^{\prime} \mathrm{E}\right)$, which is a source region of Sahelian dust. It corresponds to the first millimeters of soil that are prone to wind erosion. The finest fraction of soil with a diameter less than $20 \mu \mathrm{m}$ is representative of naturally produced dust (Alfaro and Gomes, 2001). The elemental chemical analysis of sieved soil was performed by wavelength dispersive X-ray fluorescence (WD-XRF) using a PW-2404 spectrometer by Panalytical based on the protocol described in Guieu et al. (2010). The $<20 \mu \mathrm{m}$ m fraction of soil from Niger is composed of $3.1 \pm 0.2 \% \mathrm{Fe}$ and $4.9 \pm 0.7 \% \mathrm{Al}$. The aerosol-adapted citrate bicarbonate dithionite (CBD) method described by Lafon et al. (2004) emphasizes that $70 \%$ of iron is present as iron oxide. The $\mathrm{Fe}$, which is not oxide, is mainly present as illite, a typical clay found in dust aerosols (Paris et al., 2011). The fraction of organic matter in soil has been estimated by loss-on-ignition method (Konen et al., 2002) and corresponds to $7.3 \%$ of total mass of material.

\subsection{Leaching solution}

The leaching solutions were prepared to mimic atmospheric rainwater by acidifying $18.2 \mathrm{~m} \Omega \mathrm{cm}$ ultra-pure water (Elga ${ }^{\circledR}$ Purelab) with sulphuric acid (Ultrapure, Normaton 2, Prolabo ${ }^{\circledR}$ ) at $\mathrm{pH} 4.7$, typical $\mathrm{pH}$ of remote rainwater samples (Heartsill-Scalley et al., 2007) and by diluting a working solution of the studied organic compound. Stock organic solutions $\left(10^{-2} \mathrm{~mol} \mathrm{~L}^{-1}\right)$ were prepared by dissolving pure powder organic salts (Table 1) in ultra-pure water, then diluted to the concentration of $10^{-4} \mathrm{~mol} \mathrm{~L}^{-1}$ as working solution. All organic solutions were prepared in sterilised glass flasks and stored before experiment (max. 2 weeks at $4{ }^{\circ} \mathrm{C}$ ). The used concentration of the leaching solution during the dissolution experiments corresponded to the range of measured concentrations in the rainwater from 0.5 to $8 \mu \mathrm{m}$ (Table 1). The humic acid concentrations were estimated on the basis that HULIS represent $50 \%$ of typical marine rainwater DOC (Sempéré and Kawamura, 1996). Initial organic ion concentrations (except HULIS) were checked by ionic chromatography using a Professional IC 850 by Metrohm ${ }^{\circledR}$ with a Metrosep A Supp 7-250 column. Moreover, none of the studied organic compounds were detected via ionic chromatography in the dissolved phase after leaching of Niger dust by ultrapure water under ambient laboratory conditions (temperature and light).

\subsection{Dissolution experiments}

In order to measure iron solubility in dust particles, $15 \pm 0.2 \mathrm{mg}$ of the sieved fraction of soil were put into $1 \mathrm{~L}$ of the leaching solution. This amount of soil material represents $0.465 \pm 0.006 \mathrm{mg}$ of iron (Fetot). This dust:water ratio of $15 \mathrm{mg} \mathrm{L}^{-1}$ is consistent with the observed cloud or rain conditions (Desboeufs et al., 2010). Each experiment was set for one organic compound. After $60 \mathrm{~min}$ of contact with an automatic shaker and under laboratory light (with no UV properties), the leaching solutions were filtered through a $0.2 \mu \mathrm{m}$ Nucleopore ${ }^{\circledR}$ polycarbonate filter for dissolved iron analysis. This amount of time is consistent with the processing time of aerosol into droplet between the cloud drop formation and its precipitation (Warneck, 1988). Moreover, previous studies on dissolution rates of dust showed that the highest rates are obtained in the first ten minutes and hence that most $\mathrm{Fe}$ is released in the solution in about $60 \mathrm{~min}$ 
Table 2a. Dissolved iron concentrations (nM) obtained for the dissolution experiments from Niger dust at $\mathrm{pH} 4.7$ and for various atmospheric concentrations of organic ligands.

\begin{tabular}{|c|c|c|c|c|c|c|c|c|c|c|c|c|c|c|c|c|c|c|c|c|}
\hline \multirow{2}{*}{$\begin{array}{l}\text { Organic } \\
\text { concentra- } \\
\text { tion }(\mu \mathrm{M})\end{array}$} & \multicolumn{2}{|c|}{ Formate } & \multicolumn{2}{|c|}{ Acetate } & \multicolumn{2}{|c|}{ Glycolate } & \multicolumn{2}{|c|}{ Oxalate } & \multicolumn{2}{|c|}{ Malonate } & \multicolumn{2}{|c|}{ Succinate } & \multicolumn{2}{|c|}{ Glutarate } & \multicolumn{2}{|c|}{ Tartrate } & \multicolumn{2}{|c|}{ Lactate } & \multicolumn{2}{|c|}{ Humic Acid } \\
\hline & $\mathrm{DFe}$ & $( \pm)$ & $\mathrm{DFe}$ & $( \pm)$ & $\mathrm{DFe}$ & $( \pm)$ & $\mathrm{DFe}$ & $( \pm)$ & $\mathrm{DFe}$ & $( \pm)$ & $\mathrm{DFe}$ & $( \pm)$ & $\mathrm{DFe}$ & $( \pm)$ & $\mathrm{DFe}$ & $( \pm)$ & $\mathrm{DFe}$ & $( \pm)$ & $\mathrm{DFe}$ & $( \pm)$ \\
\hline 0 & 3.22 & 0.72 & 3.22 & 0.72 & 3.22 & 0.72 & 3.22 & 0.72 & 3.22 & 0.72 & 3.22 & 0.72 & 3.22 & 0.72 & 3.22 & 0.72 & 3.22 & 0.72 & 3.22 & 0.72 \\
\hline 0.5 & & & & & & & 5.71 & 0.94 & 3.94 & 0.09 & 3.12 & 0.49 & 2.51 & 0.18 & & & & & & \\
\hline 1 & & & & & 3.05 & 0.18 & 7.01 & 0.93 & 4.83 & 0.36 & 3.58 & 0.36 & 3.22 & 0.18 & 6.09 & 0.18 & & & & \\
\hline 2 & & & & & & & 8.59 & 0.54 & 5.19 & 0.18 & 3.04 & 0.18 & 2.86 & 0.36 & & & & & & \\
\hline 3 & & & & & 3.26 & 0.18 & 11.15 & 0.50 & & & & & & & 6.27 & 0.18 & 3.15 & 0.08 & & \\
\hline 3.6 & & & & & & & & & & & & & & & & & & & 3.76 & 0.41 \\
\hline 5 & & & & & 3.1 & 0.18 & 17.42 & 0.77 & & & & & & & 7.88 & 0.18 & 3.25 & 0.18 & & \\
\hline 8 & 2.88 & 0.31 & 3.76 & 0.42 & & & 22.43 & 0.65 & & & & & & & & & 3.40 & 0.09 & & \\
\hline 10.9 & & & & & & & & & & & & & & & & & & & 4.83 & 0.36 \\
\hline 21.8 & & & & & & & & & & & & & & & & & & & 7.70 & 0.19 \\
\hline
\end{tabular}

Table 2b. Iron solubility obtained for the dissolution experiments from Niger dust at $\mathrm{pH} 4.7$ and for various atmospheric concentrations of organic ligands.

\begin{tabular}{|c|c|c|c|c|c|c|c|c|c|c|c|c|c|c|c|c|c|c|c|c|}
\hline \multirow{2}{*}{$\begin{array}{l}\text { Organic } \\
\text { concentra- } \\
\text { tion }(\mu \mathrm{M})\end{array}$} & \multicolumn{2}{|c|}{ Formate } & \multicolumn{2}{|c|}{ Acetate } & \multicolumn{2}{|c|}{ Glycolate } & \multicolumn{2}{|c|}{ Oxalate* } & \multicolumn{2}{|c|}{ Malonate } & \multicolumn{2}{|c|}{ Succinate } & \multicolumn{2}{|c|}{ Glutarate } & \multicolumn{2}{|c|}{ Tartrate } & \multicolumn{2}{|c|}{ Lactate } & \multicolumn{2}{|c|}{ Humic Acid } \\
\hline & $\begin{array}{l}\mathrm{SFe} \\
(\%)\end{array}$ & $\begin{array}{l}( \pm) \\
(\%)\end{array}$ & $\begin{array}{l}\mathrm{SFe} \\
(\%)\end{array}$ & $\begin{array}{l}( \pm) \\
(\%)\end{array}$ & $\begin{array}{l}\mathrm{SFe} \\
(\%)\end{array}$ & $\begin{array}{l}( \pm) \\
(\%)\end{array}$ & $\begin{array}{l}\mathrm{SFe} \\
(\%)\end{array}$ & $\begin{array}{l}( \pm) \\
(\%)\end{array}$ & $\begin{array}{l}\mathrm{SFe} \\
(\%)\end{array}$ & $\begin{array}{l}( \pm) \\
(\%)\end{array}$ & $\begin{array}{l}\mathrm{SFe} \\
(\%)\end{array}$ & $\begin{array}{l}( \pm) \\
(\%)\end{array}$ & $\begin{array}{l}\mathrm{SFe} \\
(\%)\end{array}$ & $\begin{array}{l}( \pm) \\
(\%)\end{array}$ & $\begin{array}{l}\mathrm{SFe} \\
(\%)\end{array}$ & $\begin{array}{l}( \pm) \\
(\%)\end{array}$ & $\begin{array}{l}\mathrm{SFe} \\
(\%)\end{array}$ & $\begin{array}{l}( \pm) \\
(\%)\end{array}$ & $\begin{array}{l}\mathrm{SFe} \\
(\%)\end{array}$ & $\begin{array}{l}( \pm) \\
(\%)\end{array}$ \\
\hline 0 & 0.04 & 0.01 & 0.04 & 0.01 & 0.04 & 0.01 & 0.04 & 0.01 & 0.04 & 0.01 & 0.04 & 0.01 & 0.04 & 0.01 & 0.04 & 0.01 & 0.04 & 0.01 & 0.04 & 0.01 \\
\hline 0.5 & & & & & & & 0.06 & 0.01 & 0.047 & 0.001 & 0.04 & 0.01 & 0.030 & 0.002 & & & & & & \\
\hline 1 & & & & & 0.037 & 0.002 & 0.08 & 0.01 & 0.058 & 0.004 & 0.043 & 0.004 & 0.039 & 0.002 & 0.073 & 0.002 & & & & \\
\hline 2 & & & & & & & 0.10 & 0.01 & 0.062 & 0.002 & 0.037 & 0.002 & 0.034 & 0.004 & & & & & & \\
\hline 3 & & & & & 0.039 & 0.002 & 0.13 & 0.01 & & & & & & & 0.075 & 0.002 & 0.038 & 0.001 & & \\
\hline 3.6 & & & & & & & & & & & & & & & & & & & 0.045 & 0.005 \\
\hline 5 & & & & & 0.037 & 0.002 & 0.21 & 0.01 & & & & & & & 0.095 & 0.002 & 0.039 & 0.002 & & \\
\hline 8 & 0.035 & 0.004 & 0.045 & 0.005 & & & 0.27 & 0.01 & & & & & & & & & 0.041 & 0.001 & & \\
\hline 10.9 & & & & & & & & & & & & & & & & & & & 0.058 & 0.005 \\
\hline 21.8 & & & & & & & & & & & & & & & & & & & 0.092 & 0.005 \\
\hline
\end{tabular}

* Data for "Oxalate" are issued from Paris et al. (2010) and are completed by new experiments with 0.5 and $2 \mu \mathrm{M}$ oxalate solutions.

(Desboeufs et al., 1999). All experiments were made in triplicate. The experimental conditions enabled us to use very low concentrations of about $\mu \mathrm{g} \mathrm{L}^{-1}$ (ppb) or less. To avoid extraneous contamination and to ensure very low detection limits, all dissolution experiments and analyses were conducted in a clean room (class $<1000$ ) and with laminar-flow ultraclean benches (class < 10). All leaching and sample solutions were collected in polyethylene bottles that were carefully acid washed in accordance with the cleaning protocol detailed in Desboeufs et al. (2003b). Filters were also washed by rinsing once with ultra-pure $0.2 \mathrm{M} \mathrm{HCl}$ then 3 times with ultra-pure water. The collected sample solutions were acidified at $\mathrm{pH} 1$ with ultrapure Prolabo ${ }^{\circledR}$ Normatom $\mathrm{HNO}_{3}$ to allow proper analyses. The temperature in the clean room was maintained between $20^{\circ}$ and $22^{\circ} \mathrm{C}$. In order to check the potential contaminations, 3 blank experiments were conducted in leaching solutions for each organic species but without soil addition. Dissolved iron concentrations $\left(\mathrm{DFe}_{T}\right)$ obtained for these blank experiments ranged from no measurable $(<0.6 \mathrm{nM}$, the detection limits of the instrument) to $0.9 \mathrm{nM}$. If the mean $\mathrm{DFe}_{T}$ of the blank experiments of organic species was measurable, this blank value was deducted from the measured $\mathrm{DFe}_{T}$ of corresponding dissolution experiments. Niger soil does not contain calcite or carbonated minerals and hence its buffering capacity is insignificant. How- ever, as the used solution is not buffered, the $\mathrm{pH}$ is measured in the initial solution and at the end of the experiment to check that it is fixed at 4.7. For all experiments, this $\mathrm{pH}$ was stable.

\subsection{Dissolved iron measurement}

Dissolved iron concentration $\left(\mathrm{DFe}_{T}\right)$ was analyzed by a Perkin Elmer Optima 3000 XL ICP-AES (Inductively Coupled Plasma Atomic Emission Spectrometer), which has a detection limit of $0.6 \mathrm{nM}$ for $\mathrm{Fe}$ (Desboeufs et al., $2003 b)$. The iron solubility (\% SFe) is calculated as follows: $\% \mathrm{SFe}=100 \times\left(\mathrm{DFe}_{T} / \mathrm{Fe}_{\text {tot }}\right)$. For some experiments, the dissolved $\mathrm{Fe}(\mathrm{II})$ (DFe(II)) was determined by a modification of spectrophotometric ferrozine method (Kieber et al., 2005). Absorbance of the iron ferrozine complex was read at $562 \mathrm{~nm}$ using a $1 \mathrm{~m}$ liquid wave-guide capillary cell attached to a JAZ spectrometer (Ocean Optics, World Precision Instruments). Absorbance measurements were referenced to a nonabsorbing wavelength $(700 \mathrm{~nm})$ in order to compensate for turbidity and instrument drift. Preliminary analysis of each tested organic species solution spiked with known Fe(II) content showed that the formation of iron ferrozine complex was not affected by the presence of studied organic binding ligand in the solution. The detection limit of the Fe(II) method is 
$2 \mathrm{nM}$. DFe(III) was determined by the difference between $\mathrm{DFe}_{T}$ and $\mathrm{DFe}(\mathrm{II})$.

\section{Results and discussion}

\subsection{Iron solubility and redox speciation}

We have carried out 6 dissolution experiments without organic species and it has been determined that the mean solubility for Niger aerosol analogues is about $0.04 \% \pm 0.01 \%$, i.e. $180 \mathrm{ng} \pm 40 \mathrm{ng}$ of dissolved iron for each experiment (Tables $2 \mathrm{a}$ and $\mathrm{b}$ ). This shows that the $<20 \mu \mathrm{m} \mathrm{m}$ fraction of soil, analogue of dust collected before atmospheric transport, is poorly soluble. This result is consistent with previous works on dust-iron solubility from proxies for mineral dust (e.g. Desboeufs et al., 2005; Mackie et al., 2006). This solubility value corresponds to a release of dissolved iron $3.22 \mathrm{nM} \pm 0.72 \mathrm{nM}$. The redox speciation of the dissolved iron shows that $\mathrm{DFe}(\mathrm{II})$ is below the limits of detection of LWCC method of $2 \mathrm{nM}$. This result shows that less than $2 \mathrm{nM}$ of $\mathrm{DFe}_{T}$ is present as $\mathrm{Fe}(\mathrm{II})$, i.e. $\mathrm{DFe}(\mathrm{II})$ represents less than $60 \%$ of $\mathrm{DFe}_{T}$.

The results obtained in the presence of organic compounds are detailed in Tables 2a and b. For the 10 studied organic compounds, it appears that the iron solubility obtained for 6 of these compounds is $0.04 \%$, i.e. the same as the one determined without organic compounds, meaning no significant effect on dust iron solubility. This is the case for acetate, formate, glycolate, succinate, glutarate and lactate, whereas an increase of iron solubility is observed for 4 organic compounds, i.e. oxalate, malonate, tartrate and the analogue of HULIS. As previously mentioned regarding motivation of this paper, very few data exists on the effect of atmospheric organic compounds. The promoting effect of oxalate on iron solubility under dark conditions is consistent with other works carried out on pure minerals or from fine fraction of soil (Xu and Gao, 2008 (hematite); Paris et al., 2011 (goethite, illite, various Saharan dust analogues)). In contrast, our results are not in agreement with the observations of Pehkonen et al. (1993), Siefert et al. (1994) and Upadhyay et al. (2011) which emphasize the positive effect of acetate and formate on the iron solubility from iron oxyhydroxides and ambient aerosols. It is known that the origin of iron (dust-bearing or anthropogenic) is crucial to estimate its solubility (Desboeufs et al., 2005). The aerosol particles used by Upadhyay et al. (2011) and Siefert et al. (1994) were collected in regions of anthropogenic influence whereas our particulate matter is soil matter. In consequence, the effect of organic compounds could be dependent on the origin of the iron. Pehkonen et al. (1993) and Siefert et al. (1994) carried out dissolution experiments under UV light. Pehkonen et al. (1993) attributed the promoting effect of acetate and formate on iron dissolution to the photo-production of Fe(II) from $\mathrm{Fe}(\mathrm{III})$-oxyhydroxides, a process which is impossible in our study carried out under no-UV light. However, to explain the difference of results, it is important to also take into consideration that the studied concentrations in those works were 60 to 600 higher than in our study, i.e. much higher than the atmospheric concentrations. For those studies, the amount of Fe extracted in acetate and formate solutions increased by a factor of 10 in the best case. In our study we have found that iron solubility increases from $0.04 \%$ to $0.26 \%$ (Table 2a) in the presence of atmospheric concentrations of oxalate, i.e. by a factor of 6.5. In consequence, our results emphasize that the organic complexation by oxalate is almost as effective on iron solubility as the effect of formate and acetate at extreme concentrations. Knowing the impact of photochemical process in the presence of formate and acetate on iron solubility, studies of iron dust solubility under UV irradiation in the presence of oxalate, malonate, tartrate and macro-organic HULIS-type ligands should be carried out.

Due to the proximity of dissolved iron concentrations with the detection limit of $\mathrm{Fe}$ (II) method, the measurements of redox iron speciation were only determined for the experiments with the highest concentrations of organic compounds. The DFe(II) concentrations were below the detection limit for all organic compounds that did not increase iron solubility. For the other organic compounds, the percentages of dissolved $\mathrm{Fe}$ (II) ranged from $66 \%$ for humic acid to $78 \%$ for oxalate. This means an increase of release of $\mathrm{Fe}(\mathrm{II})$ in comparison to experiments without organic compounds. Thus, our results suggest that the initial dissolved iron is mainly $\mathrm{Fe}(\mathrm{II})$-organic complex under dark conditions. These Fe(II) ratings are in the same order of magnitude as those reported in the literature, where $\mathrm{DFe}(\mathrm{II}) / \mathrm{DFe}_{T}$ mean ratios higher than $50 \%$ are observed in the atmospheric waters (Behra and Sigg, 1990; Özsoy and Saydam, 2001; Kieber et al., 2001). It is known that iron redox species are involved in numerous (photo)chemical reactions in cloud- and raindrops, such as the oxidation of $\mathrm{S}(\mathrm{IV})$, the budget of $\mathrm{H}_{2} \mathrm{O}_{2}$, the formation of free radicals $\left(\mathrm{OH}, \mathrm{HO}_{2} / \mathrm{O}_{2}^{-}\right)$and the oxidation of ozone (Erel et al., 1993; Deguillaume et al., 2004; Ben'ko and Lunin, 2010). This modifies the redox cycling between $\mathrm{Fe}(\mathrm{II})$ and $\mathrm{Fe}(\mathrm{III})$ and implies a temporal pattern of $\mathrm{Fe}(\mathrm{II})$ and $\mathrm{Fe}(\mathrm{III})$ ratio with predominance of $\mathrm{Fe}$ (II) throughout the day (Zhu et al., 1997; Siefert et al., 1998; Kieber et al., 2001, Deutsch et al., 2001). Thus, the organic Fe(II)-complexes released by dissolution could be not stable. Nevertheless, recent works of Deguillaume et al. (2010) show the daytime dissolved concentrations of $\mathrm{Fe}$ (II) into cloud droplets are controlled both by the initial $\mathrm{DFe}(\mathrm{II}) / \mathrm{DFe}{ }_{T}$ ratio upon dissolution of immersed particles and by the photochemical reactions into droplets. Moreover, Kieber et al. (2005) observed that $25 \%$ of the $\mathrm{Fe}(\mathrm{II})$-complexing ligands in rainwater is strong enough to prevent and slow oxidation in seawater, suggesting that organic complexation enables iron to stabilize as $\mathrm{Fe}(\mathrm{II})$, probably via organic macromolecule binding ligands (Willey et al., 2008). This implies that the dissolved Fe(II) 
concentration could be significant in the aqueous phase even during the night due to the organic complexation.

\subsection{Dependence on the organic compounds concentration}

In the case of a promoting effect of organic species, it appears that a positive linear relationship exists between iron-bearing dust solubility and ligand concentrations in the range of atmospheric concentrations (Fig. 1). The positive linear correlation between dissolved iron and oxalate concentrations has been previously observed on typical pure minerals bearing iron in dust aerosols: hematite (Xu and Gao, 2008), goethite and illite (Paris et al., 2011), and also on various analogues of Saharan dust (Paris et al., 2011). Our experiments show that the slope of the positive correlation is different for each compound, meaning that their effectiveness to promote iron solubility is dependent on the nature of the ligands. Oxalate is about 14 times more effective than humic acid, which is the least effective. For a solution with an organic compound concentration of $1 \mu \mathrm{m}$, the increase of iron solubility is $126 \%$, $42 \%$ and $10 \%$ for oxalate, malonate $=$ tartrate, and humic acid, respectively. Thus, our results show a dependence of iron solubility both on the nature of organic compounds and on their ranges of atmospheric concentrations. This linear behaviour could be explained by a limitation of the iron dissolution by the concentrations of available ligands for complexing iron. However, the number of moles of organic ligands in solution is always much higher than that of the dissolved iron (Table 2a), meaning that the ligand concentrations are not limiting. The linear relation of dissolved metals with ligand concentrations is known from the studies on aquatic surface chemistry and is attributed to the dependence of dissolution to the formation of surface complexes and hence to the surface concentrations of ligands (Stumm and Morgan, 1996). Under atmospheric conditions, the formation of iron surface complexes with oxalate on hematite has been highlighted by an adsorption isotherm method (Xu and Gao, 2008). However, in our case, the prediction of surface complexes is made difficult by the use of soil compounds of various minerals. These minerals probably release various elements in solution such as transition metals $(\mathrm{Cu}, \mathrm{Mn}, \mathrm{Cr})$, which could form complexes with organic ligands and hence modify their reactivity with iron. Another hypothesis to explain the linear relation could be a time-dependent increase of dissolution rates in the presence of organic ligands, as previously observed by the pH effect (Desboeufs et al., 1999). As we used a fixed amount of time $(60 \mathrm{~min})$, it is feasible that the maximum amount of dissolved iron could not be reached within this amount of time and that the linearity could therefore be directly associated to the temporal linearity of the increase of dissolution rates. Consequently, we need further studies, such as kinetic studies or numerical simulation, to conclude the cause of the linearity.

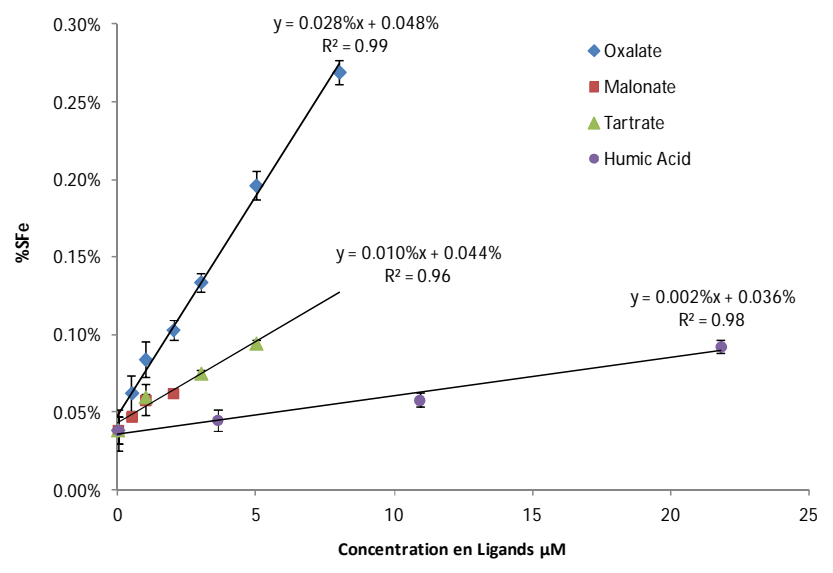

Fig. 1. Iron solubility (\%) vs. organic species concentrations ( $\mu \mathrm{m}$ $\mathrm{M})$ for the 4 species affecting iron solubility at $\mathrm{pH} 4$.7. Uncertainties represent one standard deviation of triplicate experiments.

\subsection{Dissolution process}

Under no-UV conditions, two mechanisms of ligandpromoted dissolution have been proposed for cases of dissolution of iron oxide in an aquatic environment: a nonreductive ligand-promoted dissolution (Stumm and Morgan, 1996) and a reductive ligand-promoted dissolution (Stumm and Sulzberger, 1992). In the mechanism, the organic compounds acting as ligands form relatively strong metalorganic surface complexes, which destabilize the Fe-O bond and lower the energy barrier for dissolution. This type of dissolution increases $\mathrm{Fe}$ release through the generation of dissolved forms of $\mathrm{Fe}(\mathrm{III})$, e.g. $\mathrm{Fe}\left(\mathrm{C}_{2} \mathrm{O}_{4}\right)_{n}$, in the presence of oxalate. In the second mechanism, the organic compounds play both a role as ligand, i.e. complexing agent, and as electron donor, i.e. reducing agent. The reductive dissolution is characterized by the formation of surface iron organic complexes, which leads to electron transfer in the metal-organic surface complexes, reducing $\mathrm{Fe}(\mathrm{III})$ to more soluble Fe(II), and to the subsequent detachment of free $\mathrm{Fe}(\mathrm{II})$ in solution. Our results show that the capacity for one organic ligand to promote iron-dust dissolution is not exclusively linked to its capacity to form a complex with Fe, i.e to its stability constant of Fe(III)- or Fe(III)-ligand complex. For example, malonate is a better iron ligand than tartrate (Table 1), but their effect on iron dissolution is similar (Fig. 1). This observation excludes the assumption of a non-reductive ligandpromoted dissolution. On the contrary, the increase of dissolved $\mathrm{Fe}$ (II) in the leaching solution shows a reduction of initial $\mathrm{Fe}(\mathrm{III})$, suggesting rather a reductive ligand-promoted dissolution. In this case, the difference of the effect by organic species on dissolution can be attributed to their ability to act as electron donor. Indeed, it is known that bidendate ligands, such as carboxylate groups, are Lewis bases which are good electron donors. However, the capacity of organics 
as electron donor is directly related to the structure of ligand molecules. We observe a decrease of iron solubility with the increase of the number of carbon atoms in the studied organic molecules, i.e. for di-carboxylate species: oxalate $\left(\mathrm{C}_{2}\right)$ $>$ malonate $\left(\mathrm{C}_{3}\right)>$ succinate $\left(\mathrm{C}_{4}\right)=$ glutarate $\left(\mathrm{C}_{5}\right)$, the former couple of longest compounds having no effect on the dissolution. Stumm and Morgan (1996) reported that the effect of bidentate ligands (type carboxylate) on the extent of dissolution of $\mathrm{Fe}$ oxides decreases with the increase in the length of chain for aliphatic ligands. The inductive effect of the chain of carbon atoms increases the electronegativity of $\mathrm{COO}^{-}$cluster, inhibiting the electron donor capacity. In consequence, the longer the aliphatic chain, the weaker is the capacity of the organics to donate an electron. This is the reason why oxalate and malonate promote dissolution whereas succinate and glutarate are ineffective on dissolution. In the case of the tartrate molecule (C4), the presence of $-\mathrm{OH}$ groups on the chain of carbon atoms decreases the inductive effect and could explain its impact on iron solubility. In spite of the complexity of the humic acid structure, it is known that the large variety of carboxylate groups makes humic substances good electron donors and hence they have an important role in the control of iron bioavailability in the surface waters and in soils (Allard et al., 2004). Thus, the combination of the ability as electron donor and ligand could explain the promoting effect of HULIS analogue. However, the humic acid is less effective in iron dissolution than aliphatic organic ligands. The reductive ligand-promoted dissolution is typically controlled by surface process (Stumm and Morgan, 1996). Thus, the dissolution could be dependent on the numbers of complexes (Fe-L) formed at the surface of particles. Due to the size of humic acid in comparison to aliphatic ligands, the difference in the extent of $\mathrm{Fe}$ dissolution could be attributed to the steric hindrance of these molecules limiting the access at the surface site. Thus, the dependence of iron solubility to organic ligand concentrations could be related to the nature of ligands and their consequent ability to form surface complexes. Nevertheless, numerical studies could be useful, as suggested above, to confirm this assumption.

From the assumption of a mechanism of ligand-promoted dissolution, the ineffectiveness to promote dissolution by such organic compounds can be also explained. Among studied organic compounds, the stability constants of monocarboxylic acids (formic, acetic and glycolic acid) and lactic acid are not known with $\mathrm{Fe}(\mathrm{II})$ and are very low with $\mathrm{Fe}(\mathrm{III})$ (Okochi and Brimblecombe, 2002). No significant effect on dust iron solubility for these compounds was observed due to their very low ability to complex iron in our experiments. However, this low ability could be compensated by the very high concentrations of these compounds or by the possible anthropogenic origin of the Fe-containing aerosol materials (Upadhyay et al., 2011). The results of Pehkonen et al. (1993) suggest that the photo-production of $\mathrm{Fe}$ (II) in the UV experiments could also compensate the low ability of these species as iron ligands. Nevertheless, these experiments were carried out for high formate and acetate concentrations $(6 \mathrm{mM})$ in comparison with their usual atmospheric content. This makes it difficult to estimate the effect of photo-reduction compared with the effect of high concentrations.

\section{Conclusions}

Our results show for the first time that, under atmospheric conditions, organic ligands (other than oxalate) promote iron-dust solubility even without photo-induced processes. The increase of solubility corresponds to a linear relationship between dissolved iron and organic ligands concentrations and is systematically associated with an increase of dissolved $\mathrm{Fe}$ (II) concentrations. This study also shows that among the identified atmospheric iron organic-binding ligands, oxalate is the most effective ligand enhancing iron dissolution in cloud- and rainwater, at least under no-UV irradiation. However, oxalate is not unique; tartrate, malonate and HULIS also influence the dissolution of this trace metal. We have found that iron solubility increases by a factor of 6.5 in the presence of organic species, i.e. ranges from $0.04 \%$ to $0.26 \%$. This value is consistent with the previous observed increases by reactions of dust with acidic species $\left(\mathrm{H}_{2} \mathrm{SO}_{4}\right.$ or $\mathrm{HNO}_{3}$ ) and by photochemical and cloud processing (Desboeufs et al., 2001; Hand et al., 2004; Meskhidze et al., 2005; Fan et al., 2006; Solmon et al., 2009; Luo et Gao, 2010; Paris et al., 2011). Even if the effect of atmospheric chemical processing is significant on iron dust solubility, the organic complexation does not seem to allow for dust to achieve the high iron solubility values attributed to anthropogenic aerosols reaching $95 \%$ (Sholkovitz et al., 2012). Nevertheless, this factor could be underestimated since our experiments have been carried out without UV light. Thus, the effect of photoinduced dissolution in the presence of organic species, previously identified by Pehkonen et al. (1993), remains to be investigated under atmospheric conditions. Moreover, the potential synergetic effect of the different atmospheric processes also needs to be estimated. Thus, the organic complexation could significantly affect the global distribution of the atmospheric Fe deposition fluxes to the oceans, and this process needs to be further studied.

Our work shows that the dissolution process is a reductive dissolution implying the formation of organo-ferric surface complexes, as it has been underlined with pure minerals, such as oxides and hydroxides iron. The capacity of an organic compound to dissolve iron is linked to its ability both as Fe-ligand and as electron donor. Thus, the results of this paper provide a concrete basis of work to consider the organic complexation effect in the estimation of atmospheric iron fluxes, by identifying both the effective organic species and the involved dissolution process. However, for this purpose, very few data exist on the characterisation of ironcomplexing organic ligands in atmospheric waters, limiting the incorporation of organic complexing in modeling. The 
method developed by Cheize et al. (2012) on the identification of organic forms of $\mathrm{Fe}(\mathrm{III})$ in rainwaters needs to be adapted to other classes of iron organic binding ligands. Moreover, the potential role of organic macromolecules for complexing iron, such as HULIS, should be confirmed.

The increase of dissolved Fe(II) concentrations observed during our experiments suggests that Fe, released by dissolution, could be mainly present as dissolved organic $\mathrm{Fe}$ (II) complexes. Based on the photochemical cycling of $\mathrm{Fe}$ (Deguillaume et al., 2004) and the potential stabilization of $\mathrm{Fe}(\mathrm{II})$ by organic complexation (Kieber et al., 2005), these organic $\mathrm{Fe}$ (II) complexes could be stable and hence strongly influence dissolved Fe levels in droplets. This point is particularly relevant to studying the fate of dissolved iron deposited by rain after contact with seawater and its subsequent bioavailability. For this purpose, the photochemical redox cycling of dissolved $\mathrm{Fe}$ in atmospheric waters needs to be considered similarly to iron solubility in the assessment of atmospheric iron fluxes. Moreover, humic substances being known to complex $\mathrm{Fe}$ in the ocean (Laglera and van den Berg, 2009), the role of HULIS in the stabilization of atmospheric iron after contact with seawater should be the next step in addressing the bioavailability of atmospheric dissolved iron input, for example on the base of the protocol of Kieber et al. (2003).

Acknowledgements. The authors thank Marc Benedetti for the IHSS standard. We are also thankful to the reviewers for their useful comments on the general context, which enabled us to enrich the discussion in this paper.

Edited by: B. Ervens

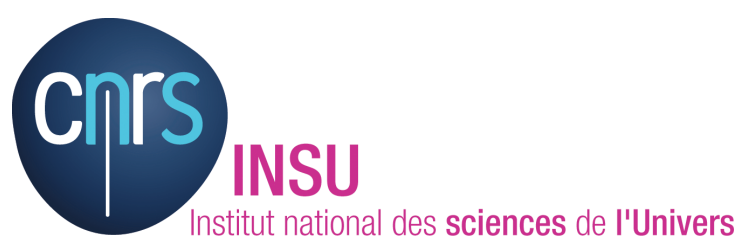

The publication of this article is financed by CNRS-INSU.

\section{References}

Alfaro, S. C. and Gomes, L.: Modeling mineral aerosol production by wind erosion: Emission intensities and aerosol size distributions in source areas, J. Geophys. Res., 106, 18075-18084, doi:10.1029/2000jd900339, 2001.

Allard, T., Menguy, N., Salomon, J., Calligaro, T., Weber, T., Calas, G., and Benedetti, M. F.: Revealing forms of iron in river-borne material from major tropical rivers of the Amazon Basin (Brazil), Geochim. Cosmochim. Ac., 68, 3079-3094, 2004.

Altieri, K. E., Turpin, B. J., and Seitzinger, S. P.: Oligomers, organosulfates, and nitrooxy organosulfates in rainwater iden- tified by ultra-high resolution electrospray ionization FTICR mass spectrometry, Atmos. Chem. Phys., 9, 2533-2542, doi:10.5194/acp-9-2533-2009, 2009.

Amato, P., Demeer, F., Melaouhi, A., Fontanella, S., Martin-Biesse, A.-S., Sancelme, M., Laj, P., and Delort, A.-M.: A fate for organic acids, formaldehyde and methanol in cloud water: their biotransformation by micro-organisms, Atmos. Chem. Phys., 7, 4159-4169, doi:10.5194/acp-7-4159-2007, 2007.

Avery, G. B., Willey, J. D., Kieber, R. J., Shank, G. C., and Whitehead, R. F.: Flux and bioavailability of Cape Fear River and rainwater dissolved organic carbon to Long Bay, southeastern United States, Glob. Biogeochem. Cycles, 17, 1042, doi:10.1029/2002gb001964, 2003.

Baker, A. R. and Croot, P. L.: Atmospheric and marine controls on aerosol iron solubility in seawater, Mar. Chem., 120, 4-13, 2010.

Barbeau, K.: Photochemistry of Organic Iron(III) Complexing Ligands in Oceanic Systems, Photochem. Photobiol., 82, 15051516, doi:10.1111/j.1751-1097.2006.tb09806.x, 2006.

Behra, P. and Sigg, L.: Evidence for redox cycling of iron in atmospheric water droplets, Nature, 344, 419-421, 1990.

Ben'ko, E. M. and Lunin, V. V.: Ozonocatalytic Decomposition of Glyoxal and Glyoxylic and Formic Acids in the Presence of Iron(III) Ions, Russ. J. Phys. Chem. A, 84, 215-220, 2010.

Buck, C. S., Landing, W. M., Resing, J. A., and Lebon, G. T.: Aerosol iron and aluminum solubility in the northwest Pacific Ocean: Results from the 2002 IOC cruise, Geochem. Geophys. Geosyst., 7, Q04M07, 2006.

Buck, C. S., Landing, W. M., Resing, J. A., and Measures, C. I.: The solubility and deposition of aerosol $\mathrm{Fe}$ and other trace elements in the North Atlantic Ocean: Observations from the A16N CLIVAR/CO2 repeat hydrography section, Mar. Chem., 120, 57-70, 2010.

Cheize, M., Sarthou, G., Croot, P. L., Bucciarelli, E., Baudoux, A.-C., and Baker, A. R.: Iron organic speciation determination in rainwater using cathodic stripping voltammetry, Anal. Chim. Acta, 736, 45-54, 2012.

Chen, Y. and Siefert, R. L.: Seasonal and spatial distributions and dry deposition fluxes of atmospheric total and labile iron over the tropical and subtropical North Atlantic Ocean, J. Geophys. Res., 109, 1-14, 2004.

Cwiertny, D. M., Baltrusaitis, J., Hunter, G. J., Laskin, A., Scherer, M. M., and Grassian, V. H.: Characterization and acid-mobilization study of iron-containing mineral dust source materials, J. Geophys. Res., 113, D05202, doi:10.1029/2007jd009332, 2008.

Deguillaume, L., Leriche, M., Monod, A., and Chaumerliac, N.: The role of transition metal ions on HOx radicals in clouds: a numerical evaluation of its impact on multiphase chemistry, Atmos. Chem. Phys., 4, 95-110, doi:10.5194/acp-4-95-2004, 2004.

Deguillaume, L., Desboeufs, K. V., Leriche, M., Long, Y., and Chaumerliac, N.: Effect of iron dissolution on cloud chemistry: from laboratory measurements to model results, Atmospheric Pollution Research, 1, 220-228, doi:210.5094/APR.2010.5029, 2010.

Desboeufs, K. V., Losno, R., and Colin, J. L.: Factors influencing aerosol solubility during cloud processes, Atmos. Environ., 35, 3529-3537, 2001.

Desboeufs, K. V., Losno, R., and Colin, J. L.: Relation between the droplet $\mathrm{pH}$ and the aerosol dissolution kinetic: Effect of the 
incorporated aerosol particles on the droplet $\mathrm{pH}$ during cloud process, J. Atmos. Chem., 46, 159-172, 2003a.

Desboeufs, K. V., Losno, R., and Colin, J. L.: Figures of merit of pneumatic and ultrasonic sample introduction systems in inductively coupled plasma-multichannel-based emission spectrometry in an ultra-clean environment, Anal. Bioanal. Chem., 375, 567-573, 2003b.

Desboeufs, K. V., Sofikitis, A., Losno, R., Colin, J. L., and Ausset, P.: Dissolution and solubility of trace metals from natural and anthropogenic aerosol particulate matter, Chemosphere, 58, 195203, 2005

Desboeufs, K., Journet, E., Rajot, J. L., Chevaillier, S., Triquet, S., Formenti, P., and Zakou, A.: Chemistry of rain events in West Africa: evidence of dust and biogenic influence in convective systems, Atmos. Chem. Phys., 10, 9283-9293, doi:10.5194/acp10-9283-2010, 2010.

Deutsch, F., Hoffmann, P., and Ortner, H. M.: Field Experimental Investigations on the $\mathrm{Fe}(\mathrm{II})-$ and $\mathrm{Fe}(\mathrm{III})-\mathrm{Content}$ in Cloudwater Samples, J. Atmos. Chem., 40, 87-105, 2001.

Erel, Y., Pehkonen, S. O., and Hoffmann, M. R.: Redox Chemistry of Iron in Fog and Stratus Clouds, J. Geophys. Res., 98, 18,423418,434, 1993.

Falkovich, A. H., Schkolnik, G., Ganor, E., and Rudich, Y.: Adsorption of organic compounds pertinent to urban environments onto mineral dust particles, J. Geophys. Res., 109, D02208, doi:10.1029/2003jd003919, 2004.

Fan, S.-M., Moxim, W. J., and Levy II, H.: Aeolian input of bioavailable iron to the ocean, Geophys. Res. Lett., 33, L07602, doi:07610.01029/02005GL024852, 2006.

Feng, J., and Möller, D.: Characterization of Water-Soluble Macromolecular Substances in Cloud Water, J. Atmos. Chem., 48, $217-$ 223, 2004

Fujisawa, N., K. Furubayashi, M. Fukushima, M. Yamamoto, T. Komai, Ootsuka, K., and Kawabe, Y.: Evaluation of the Iron(II)binding abilities of humic acids by complexometric titration using colorimetry with ortho-phenanthroline, Humic Substances Res., 8, 1-6, 2011.

Gioda, A., Mayol-Bracero, O., Morales-GarcÃ-a, F., Collett, J., Decesari, S., Emblico, L., Facchini, M., Morales-De JesÃs, R., Mertes, S., Borrmann, S., Walter, S., and Schneider, J.: Chemical Composition of Cloud Water in the Puerto Rican Tropical Trade Wind Cumuli, Water Air Soil Poll., 200, 3-14, doi:10.1007/s11270-008-9888-4, 2009.

Graber, E. R. and Rudich, Y.: Atmospheric HULIS: How humic-like are they? A comprehensive and critical review, Atmos. Chem. Phys., 6, 729-753, doi:10.5194/acp-6-729-2006, 2006.

Graham, B., Guyon, P., Maenhaut, W., Taylor, P. E., Ebert, M., Matthias-Maser, S., Mayol-Bracero, O. L., Godoi, R. H. M., Artaxo, P., Meixner, F. X., Moura, M. A. L., Rocha, C. H. E. D. A., Grieken, R. V., Glovsky, M. M., Flagan, R. C., and Andreae, M. O.: Composition and diurnal variability of the natural Amazonian aerosol, J. Geophys. Res., 108, 4765, doi:10.1029/2003jd004049, 2003.

Griffin, D. W., Kellogg, C. A., Garrison, V. H., and Shinn, E. A.: The Global Transport of Dust, Am Sci., 90, 228-235, 2002.

Guieu, C., Dulac, F., Desboeufs, K., Wagener, T., Pulido-Villena, E., Grisoni, J. M., Louis, F., Ridame, C., Blain, S., Brunet, C., Bon Nguyen, E., Tran, S., Labiadh, M., and Dominici, J. M.: Large clean mesocosms and simulated dust deposition: a new methodology to investigate responses of marine oligotrophic ecosystems to atmospheric inputs, Biogeosciences, 7, 27652784, doi:10.5194/bg-7-2765-2010, 2010.

Hand, J. L., Mahowald, N. M., Chen, Y., Siefert, R. L., Luo, C., Subramaniam, A., and Fung, I.: Estimates of atmosphericprocessed soluble iron from observations and a global mineral aerosol model: Biogeochemical implications, J. Geophys. Res., 109, doi:10.1029/2004JD004574, 2004.

Hassler, C. S., Schoemann, V. r., Nichols, C. M., Butler, E. C. V., and Boyd, P. W.: Saccharides enhance iron bioavailability to Southern Ocean phytoplankton, Proceedings of the National Academy of Sciences, 108, 1076-1081, doi:10.1073/pnas.1010963108, 2011.

Heartsill-Scalley, T., Scatena, F. N., Estrada, C., McDowell, W. H., and Lugo, A. E.: Disturbance and long-term patterns of rainfall and throughfall nutrient fluxes in a subtropical wet forest in Puerto Rico, J. Hydrol., 333, 472-485, 2007.

Hegg, D. A., Gao, S., and Jonsson, H.: Measurements of selected dicarboxylic acids in marine cloud water, Atmos. Res., 62, 1-10, 2002.

Jickells, T. D., An, Z. S., Andersen, K. K., Baker, A. R., Bergametti, G., Brooks, N., Cao, J. J., Boyd, P. W., Duce, R. A., Hunter, K. A., Kawahata, H., Kubilay, N., laRoche, J., Liss, P. S., Mahowald, N., Prospero, J. M., Ridgwell, A. J., Tegen, I., and Torres, R.: Global Iron Connections Between Desert Dust, Ocean Biogeochemistry, and Climate, Science, 308, 67-71, 2005.

Johansen, A. M., Siefert, R. L., and Hoffmann, M. R.: Chemical composition of aerosols collected over the tropical North Atlantic Ocean, J. Geophys. Res., 105, 15,277-215,312, 2000.

Journet, E., K.V. Desboeufs, S. Caquineau, and Colin, J. L.: Mineralogy as a critical factor of dust iron solubility, Geophys. Res. Lett., 35, doi:10.1029/2007GL031589, 2008.

Kieber, R. J., Williams, K., Willey, J. D., Skrabal, S., and Avery, G. B.: Iron speciation in coastal rainwater: concentration and deposition to seawater, Mar. Chem., 73, 83-95, 2001.

Kieber, R., Hardison, D. R., Whitehead, R. F., and Willey, J. D.: Photochemical Production of Fe(II) in Rainwater, Environ. Sci Technol., 37, 4610-4616, 2003.

Kieber, R. J., Skrabal, S. A., Smith, B. J., and Willey, J. D.: Organic Complexation of $\mathrm{Fe}(\mathrm{II})$ and Its Impact on the Redox Cycling of Iron in Rain, Environ. Sci. Technol., 39, 1576-1583, 2005.

Konen, M. E., Jacobs, P. M., Burras, C. L., Talaga, B. J., and Mason, J. A.: Equations for Predicting Soil Organic Carbon Using Losson-Ignition for North Central U.S. Soils, Soil Sci. Soc. Am. J., 66, 1878-1881, doi:10.2136/sssaj2002.1878, 2002.

Lafon, S., Rajot, J.-L., Alfaro, S. C., and Gaudichet, A.: Quantification of iron oxides in desert aerosol, Atmos. Environ., 38, 12111218, 2004.

Laglera, L. M. and van den Berg, C. M. G.: Evidence for geochemical control of iron by humic substances in seawater, Limnol. Oceanogr.-Meth., 54, 610-619, 2009.

Luo, C. and Gao, S.: Aeolian iron mobilisation by dust-acid interactions and their implications for soluble iron deposition to the ocean: a test involving potential anthropogenic organic acidic species, Environ. Chem., 7, 153-161, 2010

Mackie, D. S., Boyd, P. W., Hunter, K. A., and McTainsh, G H.: Simulating the cloud processing of iron in Australian dust: $\mathrm{pH}$ and dust concentration, Geophys. Res. Letters, 32, L06809, doi:10.1029/2004GL022122, 2005. 
Majestic, B. J., Schauer, J. J., and Shafer, M.: Development of a Wet-Chemical Method for the Speciation of Iron in Atmospheric Aerosols, Environ. Sci. Technol., 40, 2346-2351, 2006.

Martin, J. H., Coale, K. H., Johnson, K. S., Fitzwater, S. E., Gordon, R. M., Tanner, S. J., Hunter, C. N., Elrod, V. A., Nowicki, J. L., Coley, T. L., Barber, R. T., Lindley, S., Watson, A. J., Van Scoy, K., Law, C. S., Liddicoat, M. I., Ling, R., Stanton, T., Stockel, J., Collins, C., Anderson, A., Bidigare, R., Ondrusek, M., Latasa, M., Millero, F. J., Lee, K., Yao, W., Zhang, J. Z., Friederich, G., Sakamoto, C., Chavez, F., Buck, K., Kolber, Z., Greene, R., Falkowski, P., Chisholm, S. W., Hoge, F., Swift, R., Yungel, J., Turner, S., Nightingale, P., Hatton, A., Liss, P., and Tindale, N. W.: Testing the iron hypothesis in ecosystems of the equatorial Pacific ocean, Nature, 371, 123-129, 1994.

Mayol-Bracero, O. L., Guyon, P., Graham, B., Roberts, G., Andreae, M. O., Decesari, S., Facchini, M. C., Fuzzi, S., and Artaxo, P.: Water-soluble organic compounds in biomass burning aerosols over Amazonia 2. Apportionment of the chemical composition and importance of the polyacidic fraction, J. Geophys. Res., 107, 8091, doi:10.1029/2001jd000522, 2002.

Meskhidze, N., Chameides, W. L., and Nenes, A.: Dust and pollution: A recipe for enhanced ocean fertilization?, J. Geophys. Res., 110, doi:10.1029/2004JD005082, 2005.

Millero, F., Sotolongo, S., and Izaguirre, M.: The oxidation of Fe(II) in seawater, Geochim. Cosmochim. Acta, 51, 793-801, 1987.

Muller, C. L., Baker, A., Hutchinson, R., Fairchild, I. J., and Kidd, C.: Analysis of rainwater dissolved organic carbon compounds using fluorescence spectrophotometry, Atmos. Environ., 42, 8036-8045, 2008.

Okochi, H. and Brimblecombe, P.: Potential Trace Metal-Organic Complexation in the Atmosphere, The Scientific World Journal, 2, 767-786, doi:10.1100/tsw.2002.132, 2002.

Ooki, A., Nishioka, J., Ono, T., and Noriki, S.: Size dependence of iron solubility of Asian mineral dust particles, J. Geophys. ResAtmos., 114, D03202, 2009.

Özsoy, T. and Saydam, A. C.: Iron speciation in the North-Eastern Mediterranean and its relationship with Sahara dust, J. Atmos. Chem., 40, 41-76, 2001.

Pandey, A. K., Pandey, S. D., and Misra, V.: Stability Constants of Metal-Humic Acid Complexes and Its Role in Environmental Detoxification, Ecotox. Environ. Safe, 47, 195-200, 2000.

Paris, R., Desboeufs, K. V., Formenti, P., Nava, S., and Chou, C.: Chemical characterisation of iron in dust and biomass burning aerosols during AMMA-SOP0/DABEX: implication for iron solubility, Atmos. Chem. Phys., 10, 4273-4282, doi:10.5194/acp10-4273-2010, 2010.

Paris, R., Desboeufs, K. V., and Journet, E.: Variability of dust iron solubility in atmospheric waters: Investigation of the role of oxalate organic complexation, Atmos. Environ., 45, 6510-6517, 2011

Pehkonen, S., Slefert, R., Erel, Y., Webb, S., and Hoffmann, M. R.: Photoreduction of Iron Oxyhydroxides in the Presence of Important Atmospheric Organic Compounds, Environ. Sci. Technol, 27, 2056-2062, 1993.

Peña, R. M., García, S., Herrero, C., Losada, M., Vázquez, A., and Lucas, T.: Organic acids and aldehydes in rainwater in a northwest region of Spain, Atmos. Environ., 36, 5277-5288, 2002.

Reyes-Rodriguez, G. J., Gioda, A., Mayol-Bracero, O. L., and Collett Jr, J.: Organic carbon, total nitrogen, and water-soluble ions in clouds from a tropical montane cloud forest in Puerto Rico, Atmos. Environ., 43, 4171-4177, 2009.

Russell, L. M., Maria, S. F., and Myneni, S. C. B.: Mapping organic coatings on atmospheric particles, Geophys. Res. Lett., 29, 26 21-26-24, doi:10.1029/2002gl014874, 2002.

Sarthou, G., Baker, A. R., Blain, S., Achterberg, E. P., Boye, M., Bowie, A. R., Croot, P., Laan, P., de Baar, H. J. W., Jickells, T. D., and Worsfold, P. J.: Atmospheric iron deposition and sea-surface dissolved iron concentrations in the eastern Atlantic Ocean, Deep-Sea Res., 50, 1339-1352, 2003.

Sempéré, R. and Kawamura, K.: Low molecular weight dicarboxylic acids and related polar compounds in the remote marine rain samples collected from Western Pacific, Atmos. Environ., 30, 1609-1619, 1996.

Shi, Z., Krom, M. D., Jickells, T. D., Bonneville, S., Carslaw, K. S., Mihalopoulos, N., Baker, A. R., and Benning, L. G.: Impacts on iron solubility in the mineral dust by processes in the source region and the atmosphere: A review, Aeolian Research, 5, 21 42, 2012.

Sholkovitz, E. R., Sedwick, P. N., Church, T. M., Baker, A. R., and Powell, C. F.: Fractional solubility of aerosol iron: Synthesis of a global-scale data set, Geochim. Cosmochim. Ac., 89, 173-189, 2012.

Siefert, R. L., Pehkonen, S. O., Erel, Y., and Hoffmann, M. R.: Iron photochemistry of aqueous suspensions of ambient aerosol with added organic acids, Geochim. Cosmochim. Ac., 58, 3271-3279, 1994.

Siefert, R., Johansen, A. M., Hoffmann, M. R., and Pehkonen, S. O.: Measurements of trace metal $(\mathrm{Fe}, \mathrm{Cu}, \mathrm{Mn}, \mathrm{Cr})$ oxidation states in fog and stratus clouds, J. Air Waste Manage. Assoc., 48, 128 $143,1998$.

Siffert, C. and Sulzberger, B.: Light-induced dissolution of hematite in the presence of oxalate: a case of study, Langmuir, 7, 16271634, 1991.

Solmon, F., Chuang, P. Y., Meskhidze, N., and Chen, Y.: Acidic processing of mineral dust iron by anthropogenic compounds over the north Pacific Ocean, J. Geophys. Res.-Atmos., 114, D02305, 2009.

Stumm, W. and Morgan, J. J.: Aquatic Chemistry, 3rd edn., J. Wiley-Interscience, New York, 1022 pp., 1996.

Stumm, W. and Sulzberger, B.: The cycling of iron in natural environments: Considerations based on laboratory studies of heterogeneous redox processes, Geochim. Cosmochim. Ac., 56, 32333257, 1992.

Sullivan, R. C., and Prather, K. A.: Investigations of the Diurnal Cycle and Mixing State of Oxalic Acid in Individual Particles in Asian Aerosol Outflow, Environ. Sci. Technol., 41, 8062-8069, doi:10.1021/es071134g, 2007.

Sulzenberg, B. and Laubscher, H.: Reactivity of various types of iron(III) (Hydr)oxides towards light-induced dissolution, Marine. Chem., 50, 103-115, 1995.

Upadhyay, N., Majestic, B. J., and Herckes, P.: Solubility and speciation of atmospheric iron in buffer systems simulating cloud conditions, Atmos. Environ., 45, 1858-1866, 2011.

Warneck, P.: Chemistry of the natural atmosphere, Academic Press, San Diego, CA, 1988.

Weber, T., Allard, T., Tipping, E., and Benedetti, M. F.: Modeling Iron Binding to Organic Matter, Environ. Sci. Technol., 40, 7488-7493, doi:10.1021/es0607077, 2006. 
Willey, J. D., Kieber, R. J., Seaton, P. J., and Miller, C.: Rainwater as a source of $\mathrm{Fe}(\mathrm{II})$-stabilizing ligands to seawater, Limnol. Oceanogr., 53, 1678-1684, doi:10.4319/lo.2008.53.4.1678, 2008.

$\mathrm{Xu}, \mathrm{N}$. and Gao, Y.: Characterization of hematite dissolution affected by oxalate coating, kinetics and $\mathrm{pH}$, Appl. Geochem., 23, 783-793, 2008.

Zhu, X., Prospero, J. M., Savoie, D. L., Millero, F. J., Zika, R. G., and Saltzman, E. S.: Photoreduction of Iron (III) in marine mineral aerosol solutions, J. Geophys. Res., 98, 9039-9046, 1993.
Zhu, X., Prospero, J. M., and Millero, F. J.: Diel varability of soluble $\mathrm{Fe}(\mathrm{II})$ and soluble total $\mathrm{Fe}$ in North African dust in the trade winds at Barbados, J. Geophys. Res., 102, 21,297-221,305, 1997.

Zuo, Y.: Kinetics of photochemical/chemical cycling of iron coupled with organic substances in cloud and fog droplets, Geochim. Cosmochim. Ac., 59, 3123-3130, 1995. 